\title{
RELATIONSHIP BETWEEN GROWTH OF ANIMALS AND POLYUNSATURATED FATTY ACID
}

\author{
YUJI SUEYOSHI* and HANAKO ODA \\ Department of Biochemistry, School of Medicine, Keio University, \\ Tokyo, Japan
}

(Received for publication November 9, 1962)

Since the experiments by Allan et al.(1) and Burr et al.(2), it has been generally recognized that animals stop to grow if the polyunsaturated fatty acid is not given. The reason why the polyunsaturated fatty acid is necessary for the growth of animals was given by Ara's study(3).

The present experiment was performed to investigate the degree of response of animals to the diet deficient in the polyunsaturated fatty acid in various stages of their growth.

\section{EXPERIMENT I}

On the Relationship between the Growth of Animals in Various Stages and a Diet Deficient in the Polyunsaturated Fatty Acid

Experimental Method: Albino rats of non-pure strain were divided into 5 groups. Each group consisted of 5 rats having an average and a range of body weight as follows: Group I, $52 \mathrm{~g}$ (50-55 g); Group II, $60 \mathrm{~g}$ (57-62 g); Group III, $65 \mathrm{~g}$ (63-67 g) ; Group IV, $73 \mathrm{~g}(70-75 \mathrm{~g})$; and Group V, $53 \mathrm{~g}$ (50-55 g).

Table 1

Composition of Polyunsaturated Fatty Acid Deficient Diet

$\begin{array}{ll}\text { Starch } & 80 \% \\ \text { Casein } & 16 " \\ \text { Inorganic Salts (McCollum) } & 4 \prime \prime \\ \text { Vitamins (per } 100 \mathrm{~g} \text { of the diet) } & \\ \mathrm{B}_{1} & 0.5 \mathrm{mg} \\ \mathrm{B}_{2} & 0.5 \prime \prime \\ \mathrm{B}_{6} & 0.5 \prime \prime \\ \text { Nicotinic acid } & 1.0 \prime \prime \\ \mathrm{B}_{12} & 2 \text { gamma }\end{array}$

An aliquot of the unsaponifiable matter in cod liver oil (equivalent to $1 \mathrm{cc}$ of the cod liver oil)

* Emeritus professor of Biochemistry. 
Group V served as a control.

Group I-IV were given a diet deficient in the polyunsaturated fatty acid, the composition of which is shown in Table 1. Group V, the control, received a diet of the same composition except that linseed oil containing the polyunsaturated fatty acid was supplemented at $1 \%$ level of the diet. The growth responses of animals of each group were checked.

Results: Results are shown in Table 2. All the rats of Group I died during 49-56 days (average 52 days) of feedings (average body weight being $92 \mathrm{~g}$ at their deaths). In Group II, all the rats died during 56-72 days (average 67

Table 2.

Weight Responses of Rats in Various Growth Stages to Polyunsaturated Fatty Acid Dificient Diet

\begin{tabular}{c|c|c|c|c|c}
\hline $\begin{array}{c}\text { Group of rats } \\
\begin{array}{c}5 \text { rats in each } \\
\text { group) }\end{array}\end{array}$ & $\begin{array}{c}\text { Initial body } \\
\text { weight } \\
(\mathrm{g})\end{array}$ & $\begin{array}{c}\text { Final body } \\
\text { weight } \\
(\mathrm{g})\end{array}$ & $\begin{array}{c}\text { Weight } \\
\text { increase } \\
(\mathrm{g})\end{array}$ & $\begin{array}{c}\text { Experimental } \\
\text { period } \\
\text { (days })\end{array}$ & $\begin{array}{c}\text { Dead or alive at } \\
\text { termination of } \\
\text { experiment }\end{array}$ \\
\hline I & $50-55$ & $80-105$ & $30-55$ & $49-56$ & All dead \\
\hline Average & 52 & 92 & 42 & 52 & Dead \\
\hline II & $57-62$ & $85-130$ & $25-70$ & $56-72$ & All dead \\
\hline Average & 60 & 107 & 47 & 67 & Dead \\
\hline III & $63-67$ & $135-145$ & $70-80$ & $75-79$ & All dead \\
\hline Average & 65 & 140 & 75 & 77 & Dead \\
\hline IV & $70-75$ & $170-180$ & $100-105$ & $78-85$ & All dead \\
\hline Average & 73 & 175 & 102 & 82 & Dead \\
\hline $\begin{array}{c}\text { V (Control) } \\
\text { (C)--- }\end{array}$ & $50-55$ & $180-185$ & $120-130$ & 86 & All alive \\
\hline Average & 53 & 183 & 130 & 86 & Alive \\
\hline
\end{tabular}

days) of feeding (average body weight being $107 \mathrm{~g}$ ). In Group III, the feeding period was 75-79 days (average 77 days) when all the rats died. In Group IV, all the rats died after feeding for 78-85 days (average 82 days). In Group V, all the rats survived through 86 days of observation period. Average growthcurves of Groups I-V are illustrated in Figures 1-5, respectively.

\section{EXPERIMENT II}

\section{Study on the Amounts of Polyunsaturated Fatty Acids} in Muscles of the Mature and the Immature Rats

In Experiment I, it was found that the younger the animals, the less resistant they were to the polyunsaturated fatty acid deficiency. A reason for this may be that the younger the animals, the more rapidly they grow, that is, the more 


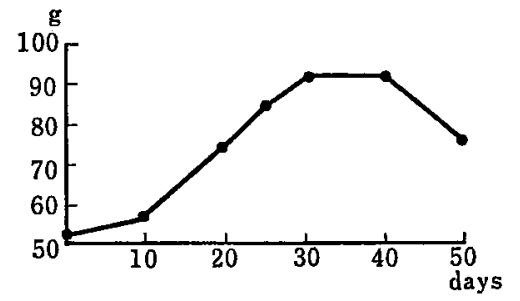

Fig. 1 Average growtl.-cu ve of Group I rats.

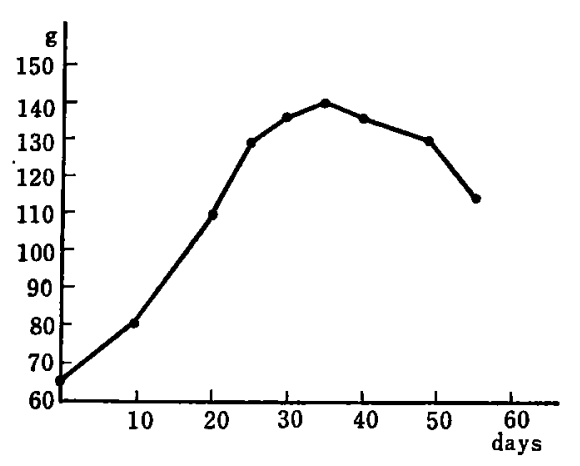

Fig. 3 Average growth-curve of Group III rats.

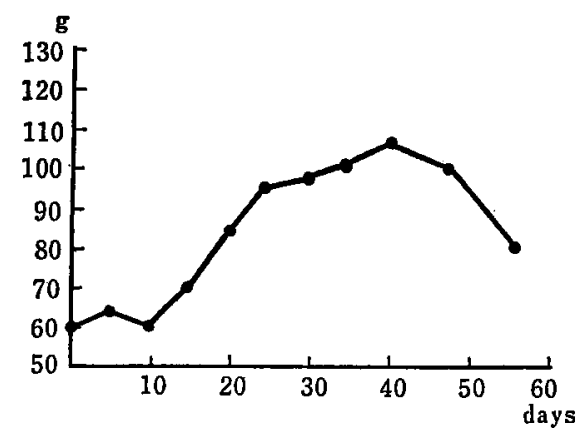

Fig. 2 Average growth-curve of Group II rats.

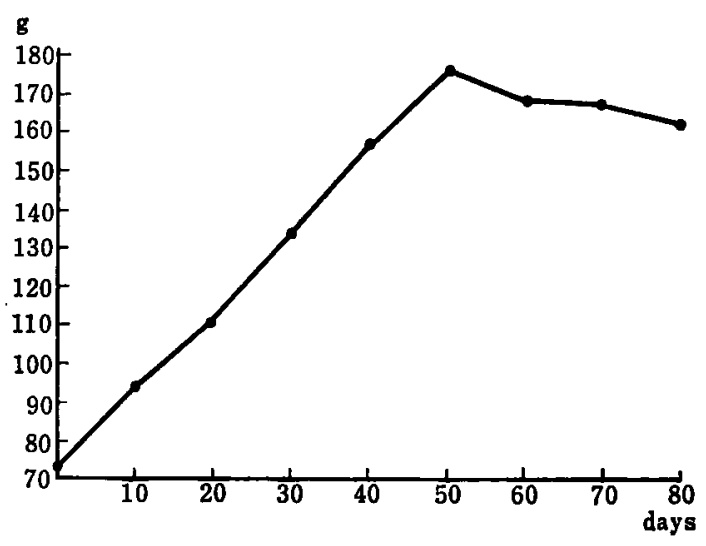

Fig. 4 Average growth-curve of Group IV rats.

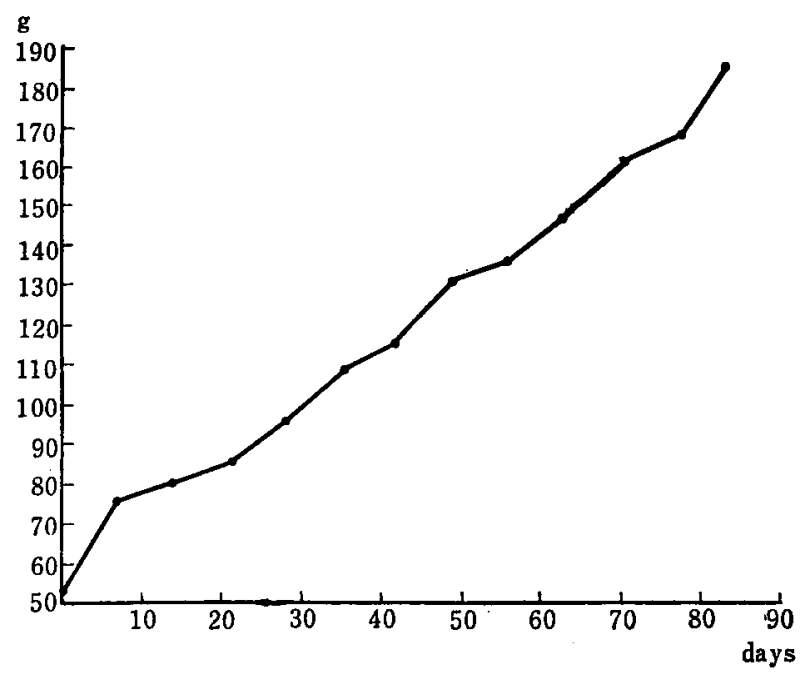

Fig. 5 Average growth-curve of Group V rats. 
vigorously new cells are formed, leading to the greater demand for the polyunsaturated fatty acid. There is, however, another possibility that the cells in younger animals may require more of the unsaturated fatty acid to compose their lipid than do the cells in adult animals. The experiment was undertaken to make this point clear.

Experimental Method: Albino rats of non-pure strain were used. The animals weighing $130-140 \mathrm{~g}$ were classed as a mature group and those weighing $60-70 \mathrm{~g}$ as an immature group. They were given only water and starved to death. The lipid of muscles was fractionated into the fat and the phosphatide and the amounts of the polyunsaturated fatty acids in each fraction were determined by Miura's method(4). Polybrominated fatty acids higher than octabrominated fatty acid were expressed as the arachidonic acid.

Results: As shown in Table 3, the amount of linoleic acid in the polyunsaturated fatty acid in the fat was $5.5 \%$ in the mature and $29.2 \%$ in the immature group, and that in the phosphatide was $33.1 \%$ in the mature and $42.3 \%$ in the immature group, indicating the amount of linoleic acid in either fraction was much more in the immature than in the mature group. The amounts of linolenic and arachidonic acids were also slightly more in the immature than in the mature group.

Table 3.

Amounts of Various Unsaturated Fatty Acids Constituting Muscle Cells in Mature and Immature Rats

\begin{tabular}{l|c|c|c|c}
\hline \multirow{2}{*}{ Fatty acid } & \multicolumn{2}{|c|}{ Mature rats } & \multicolumn{2}{c}{ Immature rats } \\
\cline { 2 - 5 } & $\begin{array}{c}\text { Fat } \\
(\%)\end{array}$ & $\begin{array}{c}\text { Phosphatide } \\
(\%)\end{array}$ & $\begin{array}{c}\text { Fat } \\
(\%)\end{array}$ & $\begin{array}{c}\text { Phosphatide } \\
(\%)\end{array}$ \\
\hline Oleic & $84.0-90.0$ & $50.2-60.0$ & $50.5-68.6$ & $28.3-75.4$ \\
\hline Average & 86.6 & 54.1 & 60.2 & 47.5 \\
\hline Linoleic & $3.0-7.1$ & $28.0-35.8$ & $22.4-33.7$ & $19.4-62.6$ \\
\hline Average & 5.5 & 33.1 & 29.2 & 42.3 \\
\hline Linolenic & $4.0-5.6$ & $6.3-8.4$ & $4.7-7.9$ & $3.8-8.3$ \\
\hline Average & 4.9 & 7.6 & 6.0 & 6.2 \\
\hline Arachidonic & $2.0-3.8$ & $4.0-5.5$ & $2.0-7.6$ & $1.1-7.6$ \\
\hline Average & 2.8 & 4.9 & 4.4 & 3.8 \\
\hline
\end{tabular}

\section{DISCUSSION AND SUMMARY}

1) When groups of rats of various body weights were fed on a diet deficient in the polyunsaturated fatty acid, all the animals in Group I (average body 
weight of $52 \mathrm{~g}$ ), Group II (average body weight of $60 \mathrm{~g}$ ), Group III (average body weight of $65 \mathrm{~g}$ ), and Group IV (average body weight of $73 \mathrm{~g}$ ) died during $56,72,79$, and 85 days, respectively. Whereas in Group V, the control (average body weight of $53 \mathrm{~g}$ ), all the animals were still alive after 86 days of feeding, this being ascribed to the supplementation to the diet with linseed oil containing the polyunsaturated fatty acid. The data also indicate that the younger the animals the less resistant they are to the polyunsaturated fatty acid deficiency.

2) There was a marked difference in the linoleic acid content of the unsaturated fatty acid in the fat of the lipid constituents of muscles between the mature $(5.5 \%)$ and the immature rats $(29.2 \%)$. The linoleic acid contents in the phosphatide was $33.1 \%$ in the mature and $42.3 \%$ in the immature rats. The amounts of linolenic and arachidonic acids were slightly more in the immature than in the mature rats.

3) The above results indicate that the younger animals die in the earlier period of feeding the polyunsaturated fatty acid deficient diet, because they require more of the polyunsaturated fatty acid to construct their cells.

4) According to Ara's data on the lipid constituents of animal cells(3), the iodine number of the fatty acid of fat is 100 and that of phosphatide is $\mathbf{1 1 5}$. When the iodine number of fatty acid is more than 100 , it cannot be attained by oleic acid alone but the polyunsaturated fatty acid must be participated. The present study revealed that the younger the animals the more of the polyunsaturated fatty acid they require.

\section{LITERATURE}

1. Allan, F. N., Bowie, D. J., MacLeod, J. J. R., and Robinson, W. L.: Brit. J. Expl. Pathol. 5: 75, 1924.

2. Burr, G. O., and Burr, M. M.: J. biol. chem. 86: 587, 1930.

3. Ara, K.: J. Biochem. 36: 1, 1944.

4. Miura, K.: J. Biochem. 29: 467, 1939. 